\title{
11. Strindberg and Musical Expressionism in Vienna
}

\author{
They really are, as Webern wrote to me yesterday: \\ "emanations from God... Schönberg - Strindberg" \\ Alban Berg
}

In 1906, on the eve of his departure for New York and the musical directorship of the Metropolitan Opera, Gustav Mahler is reported to have asked a group of younger musicians, including Schoenberg, Berg and Webern, 'What do you fellows think about Dostoyevsky nowadays?' According to Alma Mahler, who recalls the encounter in her memoirs, 'A chorus of youthful voices replied: "We don't bother with him any more. It's Strindberg now".' Although he dates the occasion two years later and attributes the response to Mahler's question to the lone voice of Anton von Webern rather than to a youthful chorus, Hans Heinz Stuckenschmidt tells much the same story in his standard biography of Schoenberg, as does Willi Reich, in his account of Alban Berg's life and works. ${ }^{2}$ Clearly, the encounter was perceived as in some way a defining moment, like a previous 'moment of literary history' [IX, 123; 2, 452] that Strindberg had himself had occasion to chronicle in a letter to the Swedish diplomat and novelist, Birger Mörner, from Berlin in January 1893, when, at a party following the première of his play Heimat on 8 January 1893, the German dramatist Hermann Sudermann had acknowledged the impact of Scandinavian writers on contemporary Germany by observing: 'Vom Norden her kommt uns das Licht!' [IX, 123; 2, 452].

Although there have been numerous intimations of Strindberg's relevance for the Vienna of Musil, Freud, Wittgenstein, Weininger, Kokoschka and Kraus in general and that of Viennese musical expressionism in particular there have been few attempts to assess the role that Strindberg played in the emergence of modernism in Austria with any precision. Writing of his first extended visit to Frida Uhl's home at Dornach in Upper Austria in 1893-4, Olof Lagercrantz, in his biography of Strindberg, invites us to imagine him in that summer of 1894 as existing in the same space with Freud, Mahler, Kraus, and Schoenberg - who was 
obsessed by Strindberg, according to Theodor Adorno, ${ }^{3}$ but he does not expand on this tantalizing juxtaposition. Nor do the two seminal studies of this period in English - Carl Schorske's Fin-de-Siècle Vienna or Allan Janik and Stephen Toulmin's Wittgenstein's Vienna - consider his possible influence on the culture they are dissecting even though both the linguistic scepticism that preoccupies Janik and Toulmin or the loss of certainty regarding the nature of individual identity and the collapse of confidence in the coherence, form and order of the social and the natural worlds that concerns Schorske might, given his documented importance in the German-speaking nations at this time, have directed their attention to Strindberg. Like Mach and Musil he had articulated the breakdown of the traditional coordinates of time and space in the prefatory note to A Dream Play; like Loos, Kraus or Schoenberg he was an enemy of the merely ornamental and sought, like the Student's father in The Ghost Sonata, a language that would express those social truths that convention contrived to conceal; like Freud he found a way of rendering both dreams and the unconscious audible and visible; and no established writer of his generation had surely paid greater attention to what Schorske, taking his cue from Hofmannsthal, describes as 'a world which... was characterized by Das Gleitende: "[T]he nature of our epoch," [Hofmannsthal] wrote in 1905, "is multiplicity and indeterminacy. It can rest only on das Gleitende [the moving, the slipping, the sliding], and is aware that what other generations believed to be firm is in fact das Gleitende". ${ }^{4}$

In general, the pioneering role of Josef Jarno at the Theater in der Josefstadt in promoting Strindberg's work on the Viennese stage has also received little recognition. ${ }^{5}$ As in Paris in the mid-1890s Strindberg's initial reception in Vienna had as much to do with his notoriety as a woman-hater as with his standing as a dramatist, and his writings were readily enlisted to play a part in the sexual politics of a period obsessed with the analysis and representation of Woman, 'Das Weib'. This is certainly the case where his impact on Weininger and Kraus is concerned. Strindberg, of course, corresponded briefly with both of them while Emil Schering, as his translator, wrote frequently to Kraus, on his own as well as Strindberg's behalf, and placed a number of Strindbergian texts that he had culled from the pages of his ongoing German edition of Strindberg's works, in Kraus's journal, Die Fackel. Indeed, between 1903 and 1912 Strindberg, with Schering as an interested intermediary, was one of the most frequent contributors to Kraus's journal, where his work continued to appear even after Kraus had severed his connections with almost all his other contributors. ${ }^{6}$

Weininger, meanwhile, had sent Strindberg a copy of Geschlecht und Charakter (Sex and Character) in which he referred to The Father as a 'mächtige Tragödie' and utilized Creditors to prove that woman has no soul and is only a sexual complement to man, shortly after its publication in May 1903. 
Strindberg responded with a brief note in which he exclaimed, 'Finally - to see the woman problem solved is a deliverance for me, and so - accept my deepest admiration and my thanks!' [XIV, 274; 2, 700], and following Weininger's suicide that October, he also wrote a short necrology which was originally published by Kraus in Die Fackel as 'Idolatrie, Gynolatrie: Ein Nachruf von August Strindberg. There, as in his posthumously published Swedish essay on Weininger, he gives a brief exposition of the latter's theory of sexual difference in which man is perceived to be a superior moral creator and woman an erotic mediocrity, devoid of intellect, a wanton whose love 'comprises fifty percent rutting and fifty percent hate' [SS 54, 413]. He concluded the essay by laying 'a wreath on [Weininger's] grave because I honour his memory as the memory of a valiant male thinker' [SS 54, 414].?

However, as Alma Mahler's anecdote suggests, Strindberg also held an important, if less publicized, significance for the composers of the Second Viennese School, Schoenberg, Berg, and Webern. Of these, Webern was the only one actually to set a Strindberg text to music. This was in the song 'Schien mir's, als ich sah die Sonne', a setting of lines from Strindberg's paraphrase of part of the Icelandic 'Song of the Sun' in The Ghost Sonata, which forms one of Webern's Four Songs for Voice and Piano, Op. 12. However, something of the veneration that he felt for Strindberg may be gauged from a comment reported, with some additional remarks, by Alban Berg in a letter to Schoenberg:

... you must believe me, when I swear to you that your works belong to the very, very highest, that they can only be considered in company with those of Beethoven, Mozart, Wagner, and Mahler and that all the others are beneath them. They really are, as Webern wrote to me yesterday: "emanations from God [Ausstrablungen Gottes]:

$$
\begin{aligned}
& \text { Beethoven - Kant } \\
& \text { Wagner - Schopenhauer } \\
& \text { Schönberg - Strindberg" }
\end{aligned}
$$

Meanwhile Berg, though he did not use Strindberg directly in his work was nevertheless given to his frequent and enthusiastic praise. Speaking for his generation in a letter to his wife, Helene, dated 16 July 1909, he lists as 'our gods, Maeterlinck, Strindberg, Mahler, [and Richard] Strauss,, later he engagingly draws her attention to Strindberg's achievement in a variety of fields, as a dramatist, autobiographer, and novelist as well as the author of 'all the other works I've not yet read but am sure are just as fine', this in contrast to Knut Hamsun who 'wrote five masterly novels as a young man... [but] has not produced anything since..$^{10}$ Berg in fact acquired Strindberg's collected works as they appeared in German, and his copies of them are heavily annotated. ${ }^{11}$ Indeed, like Schoenberg he knew the prose works as well as, if not better than, 
the plays and appears to have derived his knowledge of Strindberg mainly from his printed texts rather than from their performance in the theatre. Thus, in the same letter, it is Strindberg's 'colossal stature as a writer' rather than his standing as a dramatist on which Berg comments, and he goes on to stress his role as 'one of the most remarkable personalities of our time. We can't condemn any of his works out of hand!' Likewise, two years later, on 20 November 1911, he listed 'a book by Strindberg' along with 'a solitary tree... and a symphony by Mahler' as examples of God's finest creations, ${ }^{12}$ and the following year a letter from Berg to Webern contains a glowing tribute to Strindberg, occasioned by the dramas Advent and Crimes and Crimes. According to Berg, both plays are filled with a profound musicality, ${ }^{13}$ although he did not pause, as Evert Sprinchorn has done, to analyse the latter in terms of sonata form and argue that in this example of Strindberg's theme-centred, post-Inferno dramaturgy, '[T] he musical techniques of varying the principal themes and of transferring them from one voice to another are carried further... than in any of his other works.' ${ }^{14}$ Moreover, on at least one occasion Berg considered taking a Strindberg play as the basis for an operatic score. When, in October 1912, Schoenberg asked him if he had 'ever thought of writing something for the theater?' and added: 'Just see that you don't take the Dream Plays away from me, for I'm considering them myself. But some other Strindberg work', ${ }^{15}$ Berg replied: 'if only I had a suitable text: for the theater. I was already considering Strindberg's Chamber Plays, and now that you suggest Strindberg that of course seems all the more compelling.' ${ }^{16}$

But if Berg was an enthusiastic reader, Schoenberg - as usual - went further. Indeed, during his expressionist period which encompasses, among other works, the monodrama Erwartung (1909), the 'drama with words', Die glückliche Hand (begun 1908, completed 1913), and the oratorio fragment Die Jakobsleiter, the first textual sketches of which date from 1915, Strindberg is present as part of the complex intertextuality of Schoenberg's works. Like Berg he acquired Schering's edition as it was published by Georg Müller, beginning in 1902. In 1913, for example, his library contained 28 volumes by Strindberg, well ahead of Maeterlinck 18, Kraus 12, Dehmel 10 and Rilke $9,{ }^{17}$ and according to the musicologist John Crawford, who quotes from an unpublished letter that Schoenberg addressed in 1951 to a certain Jake Johnson in Stockholm, he had read all those works of Strindberg translated into German 'numerous times', which 'has made me one of his greatest adherents.' ${ }^{18}$

It is also possible to identify a number of circumstantial associations between Schoenberg and Strindberg as well as several points where their ideas and practice converge. There are, for example, their mutual admirations or associations in inter alia the works of J.P. Jacobsen, who provided Schoenberg with the text for his Gurrelieder (begun 1900, completed 1911) and whose novel, Fru Marie Grubbe (1876), Strindberg once considered dramatizing; 
Richard Dehmel, who Strindberg had known in Berlin in 1893, and whose Weib und Welt (Woman and World, 1896) formed the basis of Schoenberg's first masterpiece, the string sextet Verklärte Nacht (Transfigured Night, 1899); Maeterlinck, a common admiration around the turn of the century, of course; and Balzac, whose Seraphita became one of Strindberg's canonical books from the Inferno period on, ${ }^{19}$ and which Schoenberg wished to make into a stage work spanning three evenings, complete with the angelology of Swedenborg, whom he also read. ${ }^{20}$ 'Do you know it?', he asked the painter Wassily Kandinsky, in 1912: 'Perhaps the most glorious work in existence. I want to do it scenically. Not so much as theatre, at least not in the old sense. In any case, not "dramatic". But rather: oratorio that becomes visible and audible. Philosophy, religion that are perceived with the artistic senses..$^{21}$

This reaching after new genres to express finely tuned and frequently extreme states of experience is itself a common feature of both their work. And just as Strindberg explores states of half-reality and dream in Part I of To Damascus and A Dream Play where, according to his prefatory note, 'Time and place do not exist; on an insignificant basis of reality the imagination spins and weaves new patterns' [SV 46,7], so, in one of his principal expressionist works, the brief operatic score Erwartung (Expectation) in which he abandons every conventional kind of formal linkage, including leitmotiv and thematic repetition, Schoenberg carries to an ominous conclusion the tendency prevalent in the late Strindberg as well as in Wagner - to monodrama - which is part of that shift in drama away from strenuous or decisive stage action to narration and reflection that Szondi has charted in his influential Theorie des modernen Drama. ${ }^{22}$ Indeed, in a reference to To Damascus in his essay on 'Art and the Moving Pictures', Schoenberg reveals his own aspiration also to renounce 'the law of "unity of space and time" that Strindberg had demolished in his prefatory note to A Dream Play. ${ }^{23}$

More immediately, however: the nightmare atmosphere of Erwartung, in which a woman in a dark wood stumbles across the body of her lover whom she may herself have slain is (as so often in Schoenberg) both a deeply personal, partly autobiographical document and a kind of case study (the libretto was written at Schoenberg's request by Marie Pappenheim, the sister of the 'Anna O' made famous by Freud and Breuer's Studies on Hysteria) in which his atonal music becomes a language expressive less of the Schopenhauerian will than of the Freudian unconscious. Given Schoenberg's aesthetic its music is expressive as much of the composer himself as it is a realistic representation of the subject through which he chooses to express himself. As in a great deal of Strindberg's work, from To Damascus on, this aesthetic no longer seeks faithfully to reproduce the surface, the anecdote, but to express an inner world which manifests itself at its most immediate in the 'Schrei' of Expressionism, of which Erwartung is 
an extended example. 'In reality, there is only one greatest goal towards which the artist strives,' Schoenberg writes: 'to express himself. ${ }^{24}$ And again: 'art belongs to the unconscious! One must express oneself! Express oneself directly! Not one's taste, or one's upbringing, or one's intelligence, knowledge or skill. Not all these acquired characteristics, but that which is inborn, instinctive. ${ }^{25}$ And to realize his aims he has at his disposal what he believes to be the form of expression that is least contaminated by the superficies of the world: music. For, adopting the theory of Schopenhauer and Wagner that music apprehends the essence of the world directly in sounds, whereas verbal language is a mediated, secondary form of expression, he claims that 'so direct, unpolluted and pure a mode of expression is denied to poetry, an art still bound to subject matter. ${ }^{26}$

And yet, as with Strindberg, what is important for Schoenberg is the need for self expression rather than the particular medium through which the individual artist elects to express himself. Just as Strindberg's artistic experiments during the early 1890s, conducted in accord with the theories of aleatory creation that he advanced in the vivisection 'The New Arts! or the Role of Chance in Artistic Creation', gave him the freedom to develop a new artistic language that would in due course contribute to his later work as a dramatist, ${ }^{27}$ so during the years in which he abandoned the security of the tonal system, which were years of great personal as well as artistic upheaval, Schoenberg also found in painting an alternative means of expression. ${ }^{28}$ Moreover, while it is easy to overstress the affinity (Strindberg after all no more read Freud's books than he heard Schoenberg's music), the fact remains that in the early years of the century all three men were seeking a language - theatrical, musical, oneiric and verbal - in which to express the unconscious. As Donald Mitchell observes, of Schoenberg:

$\ldots$ in the years when Freud was diving into - the Unconscious, so too was Schoenberg; because in a very real sense, having abandoned tonality, and with it the 'subconsciously functioning sense of form which gave a real composer an almost somnambulistic sense of security in creating, with utmost precision, the most delicate distinctions of formal elements', Schoenberg had only his Unconscious to look to as a potential source of the means and principles of unity and organization which would replace the lost paradise of tonality. ${ }^{29}$

Strindberg likewise came to believe 'that whatever an author does in his fever is right' [VII, 103; 1, 280], and in his dramatic writing he worked towards a form of theatre in which musical values predominate. As he remarked, of the Chamber Plays of 1907, 'the motif determines the form' (motivet betingar formen [SS 50,12]), and both there, and in To Damascus and A Dream Play he developed the possibilities of a dramaturgy organized in terms of its themes rather than the inexorable logic of a determining linear causality. Moreover, as 
Schoenberg said he wished to do, he makes music with the media of the stage, as in the closing directions of the first scene of part one of To Damascus, where the spoken word is augmented by the concrete languages of the stage, including lighting, sound, gesture, costume and movement: '[The Lady] draws the veil from her face, kisses him hastily on the mouth and hurries out. The Stranger stands for a moment astonished and dazed. A high-pitched chorus of women's voices, approaching a shriek, is heard from the church. The illuminated rose window suddenly darkens; the tree above the bench stirs; the Mourners rise from their places and look up at the sky, as if they were witnessing something unusual and terrifying' [SV 39, 38].

More specifically, however, his biographer, H.H. Stuckenschmidt maintains that Schoenberg gave credence to the Strindbergian idea that suffering endured on earth was a consequence of wrongs committed in a previous existence, and he goes on to argue that 'His spiritual development had grown in a similar way to Strindberg's. ${ }^{30}$ Stuckenschmidt outlines the vicissitudes of Strindberg's development up until the autobiographical fragment Jacob Wrestles (Jakob brottas) of 1898; he then maps them roughly on to the biography of Schoenberg that he is engaged in writing, and implies that their shared initials - A S - held an almost talismanic significance for Schoenberg. ${ }^{31}$ In fact, as Stuckenschmidt points out, the autobiographical prose fragment Jacob Wrestles 'moved Schoenberg deeply and stimulated him creatively for years. He spoke about it to his most trusted friends, not only Berg and Webern, but also Erwin Stein, Heinrich Jalowetz and Karl Linke', and entertained plans to set it to music. Indeed, Berg told Webern in a letter that '[Schoenberg] wanted at that time to write to Strindberg in detail, and even had the idea of asking Strindberg for a text. ${ }^{32}$

Originally conceived as an independent work Schoenberg then had the idea of making this setting of Jacob Wrestles part of the gigantic conception he had for a text based on Balzac's Seraphita, in which Jacob Wrestles would serve as a kind of anterior narrative or pre-history for the figure of Wilfried in Balzac's novel. This emerges from a letter to Richard Dehmel, in which Schoenberg outlines his search for a libretto that would evoke a situation not unlike that in which Strindberg had found himself in the mid-1890s, that is, the troubled history of an atheist with some residue of faith who follows a path through materialism, socialism and anarchism on the way to a new encounter with God. 'For a long time,' Schoenberg wrote:

I have been wanting to write an oratorio on the following subject: modern man, having passed through materialism, socialism, and anarchy and, despite having been an atheist, still having in him some residue of ancient faith (in the form of superstition), wrestles with God (see also Strindberg's 'Jacob Wrestling') and finally succeeds in finding God and becoming 
religious.... Originally I intended to write the words myself. But I no longer think myself equal to it. Then I thought of adapting Strindberg's 'Jacob Wrestling'. Finally I came to the idea of beginning with positive religious belief and intended adapting the final chapter, 'The Ascent into Heaven', from Balzac's 'Seraphita. ${ }^{33}$

Clearly, Schoenberg recognizes his own idea in the general pattern of Strindberg's experience up to and including not only Jacob Wrestles, but also Inferno and To Damascus, for in the same letter he insists that 'It is not through any action, any blows of fate, least of all through any love of woman, that this change of heart is to come about', ${ }^{34}$ thus departing from one of the fundamental structural patterns in both these works, in the first of which the protagonist is depicted as having to choose between love and knowledge, and in the second of which a woman is instrumental in the hero's equivocal return to faith.

The oratorio in the form outlined here remained unwritten. However, in 1915 Schoenberg then wrote the text for a Symphony for Soloists, Mixed Choir and Orchestra - a Totentanz der Prinzipien - which he published, along with Die glückliche Hand, Requiem and Die Jakobsleiter as one of four Texte in 1926. Described by Stuckenschmidt as the gloomiest of all Schoenberg's inventions, ${ }^{35}$ this scenario, like other sketches from the same period in Rufer's catalogue of Schoenberg's works, continues to echo the Strindbergian situation of Inferno, Jacob Wrestles and To Damascus. Its first movement is entitled 'Turning-Point in Life' while the final section depicts 'The faith of the "disillusioned one"; the union of objective, sceptical consciousness of reality with faith', and concludes with the strikingly Strindbergian observation: 'In the simple is concealed the mystical'. ${ }^{36}$

Schoenberg's interest in Jacob Wrestles eventually bears partial fruit in Die Jakobsleiter (Jacob's Ladder), the enormous but fragmentary torso of an oratorio for which he commenced writing the music in 1917. Having written the first half in short score, he was called up for army service and never again succeeded in finding a spontaneous continuation that might have led to the completion of the work. Like Strindberg, Schoenberg worked rapidly in concentrated periods of inspiration, and what remains of Die Jakobsleiter, where there is little if any residue of Jacob Wrestles, was orchestrated posthumously from Schoenberg's sketches by one of his pupils, Winfried Zillig.

By common consent, however, it is the earlier 'drama with music', Die glückliche Hand (The Happy Hand), composed with uncharacteristic difficulty between 1910 and 1913, that bears Strindberg's imprint most clearly. In effect a monodrama like Erwartung it depicts its singing protagonist, the Man, trapped in a triangle in which the other coordinates are the Woman and the Gentleman, both mimed roles and projections of the Man's thoughts and the events that give rise to them. There is also a chorus of twelve speaking voices, six men and six women, whose faces appear through rents in a dark violet 
curtain (rather like the chorus of faces that appear in A Dream Play and Queen Christina) and ask the Man, in both the opening and the closing scenes, why he cannot avoid repeating the drama that we are witnessing here. In this the Man, who can plausibly be seen to represent the artist or creator, is discovered lying on the ground with a fantastic cat-like animal with enormous wings crouched on his back. To the sound of mocking laughter the Chorus and the creature disappear, and the Man is eventually approached by a beautiful young woman who offers him a goblet and, as with the love potion in Tristan und Isolde, appears to claim him. But she subsequently grows indifferent to him and he loses her to the 'handsome, genteel' Gentleman; who ravishes her away. In the third scene, the Man is shown Siegfried-like with a bloody sword in 'something between a machine shop and a goldsmith's workshop', along with several workers in realistic workingmen's dress. ${ }^{37}$ Dropping his sword he picks up a piece of gold lying on the ground, lays it on the anvil and, after outfacing the Workers who have been threatening him, he splits the anvil with a single blow and from the cleft draws forth a diadem, richly set with precious stones. The Woman then appears to return to him but ultimately remains with the Gentleman, after toppling a great stone down upon the Man, who is left at the end prone on the ground as in the first scene, with the stone, now resembling the fantastic animal, on top of him.

This very brief account does no more than indicate the general structure of a work that has few words, either sung or spoken, but a great deal of meticulously plotted movement and gesture, which are organized in terms of the accompanying score. There is also a complex lighting plot which at one point specifies a crescendo of light progressing from a dull red to glaring yellow by way of brown, a dirty green, dark blue-grey, violet, dark red, blood red, orange and finally yellow to accompany a crescendo of wind in the orchestra. Thus, Schoenberg develops the action through a fusion of media that recalls the ideas of Scriabin and the theories of tone and colour of his close colleague during several of these years, Kandinsky, rather than the Gesamtkunstwerk of Wagner. Indeed, in their precision Schoenberg's stage directions come as close to musical notation as might have been thought possible before the similarly compressed and tightly controlled theatrical scores of Samuel Beckett, in e.g. Footfalls or Krapp's Last Tape.

Nevertheless, for all its dislocations and gaunt yet evocative suggestiveness (indeed, perhaps precisely because of this) the residue of a plot in Die glückliche Hand has frequently called Strindberg to the minds of Schoenberg's critics. Thus, Egon Wellesz in his pioneering study of the composer observed that 'One is most likely to discover the lines on which this drama is written if one thinks of the chamber plays of Strindberg, for whose works Schoenberg had an extraordinary admiration, ${ }^{38}$ while Theodor Adorno, in his Philosophy of the New Music, had 
no hesitation in declaring that 'The subject of the drama is Strindberg's lonely man who experiences the same failures in his erotic life as in his work. ${ }^{39}$ More specifically, both Karl Wörner, in an essay on the text in the Schweizerische Musikzeitung, and John Crawford, in a study of the work as a Gesamtkunstwerk in Musical Quarterly, draw particular parallels. For Wörner, the central theme is 'the battle of the sexes' (den Kampf der Geschlechter) as it is in The Father and The Dance of Death but treated here with greater abstraction. In barely twenty minutes, Schoenberg, employing the same kind of abstract, categorical characterization that Strindberg had revived in To Damascus, spans the core of a conflict which in Strindberg extends across an entire evening. The heroic role of the artist, and in particular the forging of the gold diadem, also recalls To Damascus. 'Here Schoenberg also found the theme of gold-making... linked to a transformation of the world (Weltreformation), ${ }^{40}$ Wörner argues, with enviable confidence of an episode that is at least as reminiscent of the anvil scene in Siegfried as it is of the gold-making scene depicted in Part Two of To Damascus.

Crawford, meanwhile, sees Die glückliche Hand as an expressionist 'Ichdrama' in which the most important literary influence is Strindberg. To Damascus is again the point of reference, but here, much more interestingly, it is the work's structure as much as the character of its protagonist or the stark sexual conflict on which Crawford dwells. As he points out, what is at first sight the apparently loose structure of both these works is belied by their taut circularity. Each of them progresses towards a central episode (in Strindberg's case the Asylum scene in Part One of To Damascus; in Schoenberg's the forging of the diadem), the stages of which are then largely repeated in the second part, so that - superficially at least - the final image of each work recalls the point at which it began. For as Schoenberg himself observed:

It should be obvious to everybody that the opening scene is identical with the closing scene (except for a few mainly formal variations. I cannot say exactly the same thing twice, with me a repetition is always a further development of the idea). I ask: doesn't one gather from this that (since $4=1$ ) the closing scene could now be followed again by the second? And that this is meant to say: etcetera, every time the same again? ${ }^{41}$

However, with its parenthetical recollection of Kierkegaard's Repetition (1843), this almost querulous observation is in fact as much an anticipation of Beckett's Endgame or Play, where, as in Die glückliche Hand, a whole life, forever repeating itself, is depicted in the course of a few minutes, as it is a specific reference to $T o$ Damascus or indeed The Dance of Death, Crimes and Crimes, The Last Knight and The Protector of the Realm, where Strindberg also employs elements of what he calls 'this contrapuntal form borrowed from music' [SV 61,157]. Thus, as Strindberg remarks in a letter about the first of these plays: 


\section{Strindberg: To Damascus I}

Street Corner

Doctor's House

Hotel Room

Sea
Street Corner

Doctor's House

Hotel Room

Sea

Road

Road

Ravine

Ravine

Kitchen Kitchen

Rose Rose

Chamber Chamber

Asylum

Schoenberg: Die glückliche Hand

1. Chorus, Man

stationary

8. Chorus, Man

stationary

2. Offstage laughter

7. Offstage laughter

3. Scene with Woman,

Gentleman

6. Scene with Woman, Gentleman
4. Workshop
episode

5. Lighting

cresendo 
The art lies in the composition, which symbolizes 'The Repetition' that Kierkegaard speaks of; the action unrolls forwards to the Asylum; there it kicks against the pricks and rebounds back through the pilgrimage, the relearning, the eating of one's words, until it begins again at the same point as the action stops, and where it began. You may not have noticed how the settings unroll backwards from the Asylum, which is the spine of a book that shuts upon itself and encloses the action. Or like a snake that bites its own tail. [XII, 279-80; 2, 624]

In Warner's opinion one further dimension also links Die glückliche Hand with To Damascus, the autobiographical. 'Ihre Kunstwerke sind Selbstbekenntnisse, ${ }^{342}$ he maintains, and just as Strindberg used his drama to explore the inner significance of his personal life with Frida Uhl and her family in Dornach, so aspects of the author-composer's life emerge in Die glückliche Hand, where they achieve symbolic representation. And while, as with To Damascus, it is not essential to know of this autobiographical dimension in order for the play to function in the theatre, the triangular relationship of Schoenberg, his first wife Mathilde, and the young painter Richard Gerstl, in which she initially deserted Schoenberg to live with Gerstl only to return and leave Gerstl to commit gruesome suicide (like the painter Schwarz in Berg's Lulu he cut his throat), does provide an intense existential focus for a drama that otherwise tends towards abstraction. ${ }^{43}$ In this sense, too, of course, Den glückliche Hand has little to do with Strindberg. As Schoenberg wrote to Berg in connection with his opera Moses und Aron, which Berg presumed must have some link with Strindberg's posthumously published world-historical drama about Moses, Through Deserts to a Heredictory Domain (Genom öknar till arfland, 1903):

For the moment I can't remember what ideas Strindberg presents. But mine, my main idea, as well as the many, many explicitly stated and symbolically represented subsidiary ideas, all that is such an integral part of my own personality that Strindberg couldn't possibly have presented anything bearing even a superficial similarity. You would certainly have realized that upon reading it, especially if - and this, as you know is indispensable with my work - you had examined every word, every sentence from various angles. Today I scarcely remember what is mine, what is still mine: but one thing you must grant me (I insist on that): everything I have ever written bears a certain intrinsic similarity with myself..$^{44}$

However, rather than itemize conceivable conjunctions and convergences between Strindberg and Schoenberg, it is ultimately more to the point briefly to consider the role each played in the history of drama and music respectively. 'Die glückliche Hand came into being long before the war,' Schoenberg would 
subsequently write, 'at a time when Realism had already been superseded and Symbolism was also coming to an end. As always in such periods, one felt then that one could go no farther with the old means; that the expressive means had withered and representational possibilities were exhausted. One thirsted for new structures, new contents.'.5 His break with tonality in the years before the First World War and the emancipation of dissonance that accompanied it may be viewed either as in itself the adumbration of a new language or the necessary prelude to such an adumbration in the dodecaphonic serialism to which he moved in the 1920s. In either case, however, he places an emphasis on the expressive values of the smallest musical elements - single intervals, short motifs, etc. - and renounces the relatively stable system of meanings which the tonal system, with what Charles Rosen has called its 'large blocks of prefabricated meaning', ${ }^{46}$ afforded the composer during the nineteenth century. And this renunciation of an exhausted, and consequently uncommunicative, language follows in the wake of Strindberg's similar break with the immediate past in his post-Inferno dramas, where he abandons the plot and conflict-centred drama of the Aristotelian form and the well-made play which continues to underpin, for example, Ibsen's achievement, in favour of a thematically organized dramatic structure with (ironically) an affinity with music. ${ }^{47}$ For like so many other writers and painters during the thirty years leading up the First World War, from Mallarmé and Gauguin to Kandinsky and Thomas Mann, Strindberg had recourse to analogies with music in order to validate formal experiments that were frequently the result of a desire to turn inward and explore unconscious motives, in his case in a new theatrical language. As Walter Sokel remarks:

In them [Strindberg's 'dream plays'] projection and embodiment of psychic forces take the place of imitation of external facts; association of ideas supplants construction of plot based on logical connection of cause and effect. The old structural principle of causal interrelation between character, incident, and action gives way to a new structural pattern, closer to music than to drama - the presentation and variation of a theme.... With few exceptions, Expressionist drama conforms to an "epic" or narrative, rather than to a strictly dramatic pattern. It is not based upon the clash of independently motivated characters, but upon the showing and telling of themes... A loosely connected "life story", a series of "stations," pictures, and situations takes the place of a well-knit plot. $^{48}$

Such a drama, with its espousal of musical values, is clearly likely to prove attractive to Viennese musical expressionism, not least because such readers of Strindberg in translation might justifiably find the non-verbal elements of his dramatic art, including his symbolic use of light and colour, sound, music 
and setting as important as the verbal content. Psychic projections realized visually along with the transformation of metaphors and figures of speech into stage images as in the infernal landscape of The Dance of Death or the timearresting Mummy in The Ghost Sonata not only enable the subconscious mind to be projected on stage; they also offer a new (or rediscovered) stage language to replace an exhausted realism. In its fusion of speech, song, movement, gesture, lighting, colour and music, Strindberg's practice in his post-Inferno dramas is part of the theatrical revolution of Craig, Fuchs, Appia, Meyerhold and - in due course - Artaud, a revolution that sought to re-theatricalize the theatre by rediscovering the unique expressive qualities that distinguish it from literature in its combination of spoken and/or sung language with all the other concrete languages of the stage. In this sense Strindberg achieves what Schoenberg aspires to in his lecture on Die glückliche Hand in connection with its production in Breslau in 1928, namely 'making music with the media of the stage'. And as so often in modernist art in general, where the carrying conventions of a consensual language, whether romantic or realist, have been supplanted by a new, often elliptical, grammar and syntax, it is the medium itself that is foregrounded; in this case the stage, like the other arts, aspires to the non-representational condition of music. Or as Schoenberg observed, in his essay on 'The Relationship to the Text', first published in 1912 in Der Blaue Reiter: 'When Karl Kraus calls language the mother of thought, and Wassily Kandinsky and Oskar Kokoschka paint pictures the objective theme of which is hardly more than an excuse to improvise in colours and forms and to express themselves as only the musician expressed himself until now, these are symptoms of a gradually expanding knowledge of the true nature of art' $^{3}{ }^{9}$ 